\section{ORCID}

Hyun-Bin Kwak, https://orcid.org/0000-0002-0216-301X

Sang-Woo Park, https://orcid.org/0000-0001-9111-1811

Su-Kyung Park, https://orcid.org/0000-0003-4697-4639

Chang-Seop Lee, https://orcid.org/0000-0002-2897-2202

Seok-Kweon Yun, https://orcid.org/0000-0002-1498-3701

Han-Uk Kim, https://orcid.org/0000-0002-8030-4017

Jin Park, https://orcid.org/0000-0002-8830-5479

\section{REFERENCES}

1. Ko CJ, Elston DM. Pediculosis. J Am Acad Dermatol 2004; 50:1-12.

2. Padhi TR, Das S, Sharma S, Rath S, Rath S, Tripathy D, et al. Ocular parasitoses: a comprehensive review. Surv Ophthalmol 2017;62:161-189.

3. Turgut B, Kurt J, Catak O, Demir T. Phthriasis palpebrarum mimicking lid eczema and blepharitis. J Ophthalmol 2009; 2009:803951.

4. Micali G, Lacarrubba F, Massimino D, Schwartz RA. Dermatoscopy: alternative uses in daily clinical practice. J Am Acad Dermatol 2011;64:1135-1146.

5. DeFazio JL, Spencer P. Images in clinical medicine. Dermoscopy of phthiriasis. N Engl J Med 2010;362:e33.

\title{
A Case of Nivolumab-Induced Lichen Planus
}

\author{
Se Jin Oh, Young Hwan Choi, Hyun Jeong Byun, Seung Hwan Oh, Ji-Hye Park, Jong Hee Lee, \\ Dong-Youn Lee, Joo-Heung Lee, Jun-Mo Yang
}

Department of Dermatology, Samsung Medical Center, Sungkyunkwan University School of Medicine, Seoul, Korea

\begin{abstract}
Dear Editor:
Nivolumab, a programmed death-1 (PD-1) immune checkpoint inhibitor antibody, has demonstrated improved survival over unresectable or metastatic melanoma and locally advanced or metastatic non-small cell lung cancer $(\mathrm{NSCLC})^{1}$. This received approval in South Korea on April, 2016, for these cancers. Here, we present a case of lichen planus (LP) after nivolumab treatment in a patient with NSCLC.

A 51-year-old male diagnosed with NSCLC was referred to our dermatology department because of violaceous pla-
\end{abstract}

ques on face and neck. Pleural invasion had been found although he had undergone chemotherapy (pemetrexed and cisplatin). Accordingly, nivolumab (2 $\mathrm{mg} / \mathrm{kg} / \mathrm{d})$ had been started and administered every 3 weeks. Three months after the nivolumab treatment, he developed multiple violaceous or dusky brown flat topped plaques on face and neck. The skin lesion did not disappear so that we performed the skin biopsy. The biopsy specimen of his neck demonstrated orthokeratosis, wedge-shaped hypergranulosis, hydropic degeneration of basal layer, and dermal lichenoid lymphocytic infiltration (Fig. 1). We diag-

\footnotetext{
Received March 29, 2018, Revised May 4, 2018, Accepted for publication May 15, 2018
}

Corresponding author: Ji-Hye Park, Department of Dermatology, Samsung Medical Center, Sungkyunkwan University School of Medicine, 81 Irwon-ro, Gangnam-gu, Seoul 06351, Korea. Tel: 82-2-3410-6578, Fax: 82-2-3410-3869, E-mail: jh1204.park@samsung.com ORCID: https://orcid.org/0000-0002-6699-5202

This is an Open Access article distributed under the terms of the Creative Commons Attribution Non-Commercial License (http://creativecommons.org/ licenses/by-nc/4.0) which permits unrestricted non-commercial use, distribution, and reproduction in any medium, provided the original work is properly cited.

Copyright (C) The Korean Dermatological Association and The Korean Society for Investigative Dermatology 

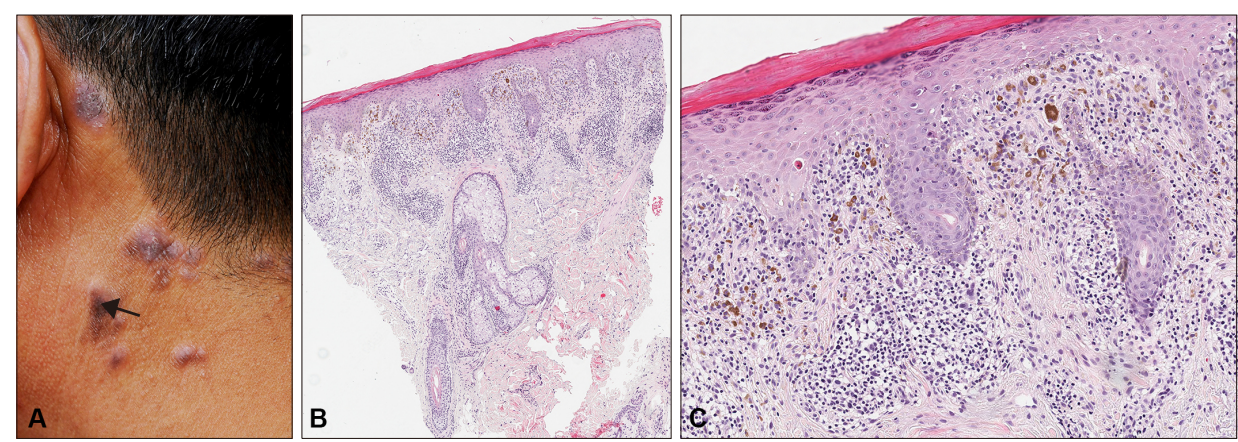

Fig. 1. (A) Violaceous or dusky brown flat-topped plaques arrow on the patient's neck. (B) Orthokeratosis, wedge-shaped hypergranulosis, and saw-toothed irregular elongated rete ridges in the epidermis. Subepidermal cleft and lichenoid lymphocytic infiltration in the dermis $(\mathrm{H} \& \mathrm{E}$, $\times 40$ ). (C) Dyskeratotic cells in the epidermis $(\mathrm{H} \& \mathrm{E}, \times 100)$.

Table 1. Anti-PD-1 therapy-induced lichen planus: review of the literature

\begin{tabular}{|c|c|c|c|c|c|c|c|c|c|c|}
\hline No. & $\begin{array}{l}\text { Age } \\
(\mathrm{yr})\end{array}$ & Sex & Cancer & $\begin{array}{l}\text { Anti-PD-1 } \\
\text { antibody }\end{array}$ & $\begin{array}{l}\text { Predisposing } \\
\text { factor }\end{array}$ & $\begin{array}{c}\text { Occurrence } \\
\text { after initiation of } \\
\text { nivolumab (mo) }\end{array}$ & Location & $\begin{array}{l}\text { Treatment of } \\
\text { side-effect }\end{array}$ & $\begin{array}{l}\text { Outcome of } \\
\text { side-effect }\end{array}$ & Reference \\
\hline 1 & 87 & M & $\begin{array}{l}\text { Not } \\
\text { mentioned }\end{array}$ & Pembrolizumab & - & 12 & $\begin{array}{l}\text { Buccal cavity, } \\
\text { tongue, penis }\end{array}$ & $\begin{array}{l}\text { Topical } \\
\text { corticosteroids }\end{array}$ & Resolved & 1 \\
\hline 2 & 46 & $M$ & Melanoma & Pembrolizumab & - & 5 & $\begin{array}{l}\text { Hand, feet, } \\
\text { forearm, trunk }\end{array}$ & $\begin{array}{l}\text { Topical } \\
\text { corticosteroids }\end{array}$ & Resolved & 1 \\
\hline 3 & 67 & $\mathrm{~F}$ & $\begin{array}{l}\text { Breast } \\
\text { cancer }\end{array}$ & Nivolumab & Radiotherapy & 5 & Extremities & $\begin{array}{l}\text { Systemic \& topical } \\
\text { corticosteroids }\end{array}$ & Resolved & 5 \\
\hline 4 & 67 & $\mathrm{~F}$ & $\begin{array}{l}\text { Breast } \\
\text { cancer }\end{array}$ & Nivolumab & Radiotherapy & 5 & Back & $\begin{array}{l}\text { Topical } \\
\text { corticosteroids }\end{array}$ & $\begin{array}{l}\text { Resolved after } \\
\text { cessation }\end{array}$ & 4 \\
\hline 5 & 52 & M & NSCLC & Nivolumab & - & 3 & Head, neck & $\begin{array}{l}\text { Topical } \\
\text { calcineurin } \\
\text { inhibitor }\end{array}$ & Resolved & $\begin{array}{l}\text { Present } \\
\text { case }\end{array}$ \\
\hline
\end{tabular}

PD: programmed death, M: male, F: female, NSCLE: non-small cell lung cancer, -: none.

nosed the lesions with LP and started with topical calcineurin inhibitor. A few weeks later, the skin lesions improved markedly. Treatment with nivolumab is currently ongoing. We received the patient's consent form about publishing all photographic materials.

Drug-induced LP is a rare cutaneous side effect of several drugs, such as antimalarials, beta-blockers, gold salts, methyldopa, or quinidine ${ }^{2}$. The time from drug administration to the appearance of the lesion varies from one month to one year or more. Typical cutaneous lesions of drug-induced LP are similar to idiopathic LP, with a symmetrical eruption of flat-topped, erythematous or violaceous papules on the trunk and extremities. However, drug-induced LP rarely shows distribution of flexural area, which is common in idiopathic LP. In addition, mucosal involvement is less common in drug-induced $\mathrm{LP}^{3}$.

Both drug-induced LP and idiopathic LP cannot be distinguished principally by histology. In drug-induced LP, the stratum granulosum is not always hypertrophic, hypergranulosis can be missing and dermal infiltrate may contain eosinophils and plasma cells. However, these differ- ences are often subtle and not reliable ${ }^{2}$, as in our case. LP is a T-cell-mediated chronic inflammatory disease that develops in skin and mucosa ${ }^{1,2,4}$. Anti-PD-1 therapy induces T-cell activation by inhibiting the suppressive effect of PD-1 signaling on T cells and induces anti-tumor effects in various cancers. Although the pathological mechanisms that induced LP by nivolumab remain unknown, the excess activation of T-cell through nivolumab is a possible explanation ${ }^{1,4,5}$.

There are several reports of LP associated with Anti-PD-1 therapy (Table 1$)^{1,4,5}$. Two patients received pembrolizumab and three patients received nivolumab. LP developed 3 to 12 months after starting Anti-PD-1 therapy. In the present case, skin lesion developed 3 months after nivolumab therapy itself. Two cases were associated with nivolumab after radiotherapy. They have been reported that radiation also affects anti-tumor immunity by induction of cell death chemokine production to recruit T-cell. In all cases, LP improved and almost healed after systemic/topical corticosteroid or topical calcineurin inhibitor. Management of idiopathic LP is challenging, but Anti-PD-1 therapy-induced 
LP improved by conventional treatment or discontinuation of drug.

In summary, physicians should be aware of the potential development of such cutaneous adverse events when administrating nivolumab therapy.

\section{CONFLICTS OF INTEREST}

The authors have nothing to disclose.

\section{ORCID}

Se Jin Oh, https://orcid.org/0000-0001-7525-4740

Young Hwan Choi, https://orcid.org/0000-0003-4177-7724

Hyun Jeong Byun, https://orcid.org/0000-0002-4354-5655

Seung Hwan Oh, https://orcid.org/0000-0002-0685-0562

Ji-Hye Park, https://orcid.org/0000-0002-6699-5202

Jong Hee Lee, https://orcid.org/0000-0001-8536-1179

Dong-Youn Lee, https://orcid.org/0000-0003-0765-9812

Joo-Heung Lee, https://orcid.org/0000-0002-1121-2055
Jun-Mo Yang, https://orcid.org/0000-0003-0656-8046

\section{REFERENCES}

1. Hofmann L, Forschner A, Loquai C, Goldinger SM, Zimmer L, Ugurel S, et al. Cutaneous, gastrointestinal, hepatic, endocrine, and renal side-effects of anti-PD-1 therapy. Eur J Cancer 2016;60:190-209.

2. Ellgehausen $P$, Elsner P, Burg G. Drug-induced lichen planus. Clin Dermatol 1998;16:325-332.

3. Goldsmith LA, Katz SI, Gilchrest BA, Paller AS, Leffell DJ, Wolff K. Fitzpatrick's dermatology in general medicine. 8th ed. New York: McGraw Hill Medical, 2012:304.

4. Komori T, Honda T, Irie H, Otsuka A, Kabashima K. Lichen planus in irradiated skin during nivolumab treatment. Acta Derm Venereol 2017;97:391-392.

5. Komori T, Honda T, Irie H, Otsuka A, Kabashima K. Multiple erosive lichen planus preceded by solitary lichen planus after combination therapy with nivolumab and radiation. J Eur Acad Dermatol Venereol 2017;31:e382-e384.

\title{
Alitretinoin Treatment for Gefitinib-Induced Paronychia
}

\author{
Soo Young Lee, Jin-Wou Kim, Dong Soo Yu, Young Bok Lee \\ Department of Dermatology, College of Medicine, The Catholic University of Korea, Seoul, Korea
}

\begin{abstract}
Dear Editor:
Gefitinib is an epidermal growth factor receptor (EGFR) inhibitor used for various cancers, especially lung cancer. It is known to affect epidermal keratinocyte of skin and commonly induce variable dermatologic reactions including follicular and pustular rash, paronychia and fissuring, hair changes, dry skin, hypersensitivity reactions, and mucosi-
\end{abstract}

\section{Received March 27, 2018, Revised May 24, 2018, Accepted for publication May 26, 2018}

Corresponding author: Young Bok Lee, Department of Dermatology, Uijeongbu St. Mary's Hospital, College of Medicine, The Catholic University of Korea, 271 Cheonbo-ro, Uijeongbu 11765, Korea. Tel: 82-31-820-5025, Fax: 82-31-846-4799, E-mail: lyb80@catholic.ac.kr ORCID: https://orcid.org/0000-0002-8642-2479

This is an Open Access article distributed under the terms of the Creative Commons Attribution Non-Commercial License (http://creativecommons.org/ licenses/by-nc/4.0) which permits unrestricted non-commercial use, distribution, and reproduction in any medium, provided the original work is properly cited.

Copyright (c) The Korean Dermatological Association and The Korean Society for Investigative Dermatology 